\title{
Role of Vamana and Padhabhayanga in the Management of Vipakdika With special reference to Plantopalmar Psoriasis
}

\author{
Case report
}

\section{Padma Priya N1*, Praveen Kumar Madikonda ${ }^{2}$, Johar B ${ }^{3}$}

1. Post Graduate scholar, 2. Associate Professor, 3. HOD

PG Department of Panchakarma, Dr. BRKR Government Ayurvedic Medical College, Hyderabad, Telangana.

\begin{abstract}
Ayurveda described various skin diseases under the single heading Kushta. In Charaka Samhita, Acharya Charaka explained Ashtadasha Kushtas in two main categories namely 'Maha Kushta' and 'Kshudra Kushta'. Kushta is tridoshaja vyadi, however, the symptoms appear according to the dosha predominance. Vipadika is one of the Kshudra Kushta with predominance of vata kapha doshas and it is charactrised by Pani Pada sputana (fissures in palms and soles) and Teevra vedana (severe pain). According to clinical manifestations, Vipadika is more similar to 'Planto Palmar Psoriasis' which is long lasting Auto Immune disease. It is found to be $3-4 \%$ of all Psoriasis cases. In modern science, many treatment modalities are available to treat the disease. They may cause many side effects and recurrence after subside is also very common which gave a big scope to alternative system of medicines to treat Vipadika. In the present case study, the line of management followed was mentioned by Acharya Charaka, according to dosha Predominance. The patient, initially administered sneha pana with Maha Tiktaka gritha for 7 days which was beneficial to pacify pitta dosha and kapha dosha utkleshana before Vamana. Later on, Vamana therapy was conducted to eliminate kapha dosha which gave good symptomatic relief to the patient. However, in view of the severity, chronicity and recurrence of the disease, Mridu Lavana jala Avagaha Sweda followed by Padhabyanga with pinda taila was also performed which resulted in excellent improvement in very short period of time.
\end{abstract}

Key Words: Vipadika, Planto Palmar Psoriasis, Vamana, Mridu Lavana jala Avagaha sweda, Padhabyanga.

\section{Introduction}

Psoriasis is a genetically determined disorder charactrised by development of chronic, well -defined scaly, erythematous plaques on the extensor aspect of the extremities especially on the elbows and knees, trunk, back, scalp, nails, palms and soles. Psoriasis can be classified as generalized and localized. The estimated prevalence is 1.5 to $3.5 \%$ in the general population. It has bimodal peak of incidence at 16-22yrs and 57-60 years. Female predominance is noted in the younger age group.

Psoriasis is considered to be an auto immune disease and has a strong genetic predilection in the form polygenic autosomal dominant inheritance with variable penetrance HLA-CW6 is implicated in psoriasis and HLA-B27, HLA-B16 in psoriatic arthropathy.

The precipitating and aggravating factors, such as physiological changes of puberty and pregnancy.

* Corresponding Author:

Padma Priya N

PG scholar,

PG Department of Panchakarma,

Dr. BRKR. Government Ayurvedic Medical College,

Hyderabad, Telangana.

Email id - sunkararao18@,gmail.com
Intercurrent infections, endocrine imbalance, physical trauma and mental stress, have a definite role in the course and prognosis of the disease. Drugs like beta blockers, anti-malaria's, NSAIDS, Lithium etc are known to cause Psoriasis form drug reactions and also to precipitate the disease. Obesity and chronic alcoholism are known to be associated with refractory cases. (1)

Several distinct forms of psoriasis are recognized, one of them is Planto-palmar psoriasis, it manifests as keratotic scaly patches and plaques on the palms and soles very frequently which accompany with fissures which can be painful. (2)

In Ayurveda it can be correlated with Vipadika, Which is one of the type of Kshudra Kushta with vata kapha predominance and it is charactrised by Pani pada sputanam( fissures in palms and soles),Teevra vedana(severe pain) by Acharya Charaka,(3) And Ashtanga Hridaya Kara added symptoms Manda kandu (mild itching), Saraga Pidaka (studded with red colored eruptions)(4) to Vipadika.

\section{Aims and objectives}

- To evaluate Samanya Chikista sutra for Kushta mentioned by Acharya Charaka in Vipadika.

- To evaluate Mridu Lavana jala Avagaha sweda and Padhabyanga with Pinda Taila in Vipadika 
Padma Priya $N$ et.al., Role of Vamana and Padhabhaynaga in the management of Vipakadika w.s.r. Plantopalmar Psoriasis

\section{Materials and methods}

The treatment given to the patient was in accorandance with the treatment principles given in Charaka Chikista Kushta Roga Adyayaya (5) i.e Line of management according to dosha predominance later on performed Mridu Lavana jala Avagaha sweda (6) followed by Padhabyanga (7) with Pinda Taila (8) in view of their benefits mentioned in our classics and considering chronicity, severity and recurrence of the disease.

\section{Case Report}

A 24-year-old male patient came to Panchakarma OPD (op no 34703) of Dr. B.R.K.R Govt. Ayurvedic Medical College on 24th November 2018 with complaints of cracks on palms and soles (more on soles) with itching, oozing, mild burning sensation, blackish discoloration of the skin with severe pain since 1 year. On examination multiple fissures on both soles appear (less on palms), watery discharge, discoloration of the skin with local tenderness. According to clinical features, the patient was diagnosed as a case of Vipadika (Planto-palmar psoriasis). Previously he has taken contemporary system medicines for 6 months and got temporary relief only.

In the above case, clinical features indicated predominance of vata and kapha doshas, hence planned general line of management mentioned by Acharya Charaka for Kushta and Avagaha sweda followed by Padhabyanga as mentioned below (Table no 1)

Treatment protocol

Table no 1: Shodhana Chikitsa

\begin{tabular}{|c|c|c|c|c|c|}
\hline $\begin{array}{l}\text { SL. } \\
\text { NO }\end{array}$ & $\begin{array}{c}\text { Type of } \\
\text { Treatment }\end{array}$ & Name of the Medicine & Dose \& Anupana & Duration & Results \\
\hline 1 & $\begin{array}{l}\text { Deepana \& } \\
\text { Pachana }\end{array}$ & $\begin{array}{l}\text { Chitrakadi vati } \\
\text { Hingwashatak } \\
\text { chooran }\end{array}$ & $\begin{array}{c}1 \text { BD } \\
\text { 2gms BD with } \\
\text { water }\end{array}$ & For first 3 days & $\begin{array}{c}\text { Nirama Lakshanas } \\
\text { observed. }\end{array}$ \\
\hline 2 & Sneha panam & Maha Tiktaka Gritha & $\begin{array}{l}\text { Day-1 } 30 \mathrm{ml} \\
\text { Day-2 } 50 \mathrm{ml} \\
\text { Day-3 } 70 \mathrm{ml} \\
\text { Day-4 } 90 \mathrm{ml} \\
\text { Day-5 } 110 \mathrm{ml} \\
\text { Day-6 } 130 \mathrm{ml} \\
\text { Day-7 } 150 \mathrm{ml}\end{array}$ & $\begin{array}{l}\text { For Next } 7 \text { days } \\
\text { (4th to } 10^{\text {th }} \text { day) }\end{array}$ & $\begin{array}{l}\text { Samyak Snigdha } \\
\text { Lakshanas observed }\end{array}$ \\
\hline 3 & $\begin{array}{l}\text { Abhyanga \& } \\
\text { Nadi sweda }\end{array}$ & Tila Tailam & $\begin{array}{c}\text { Abhyanga for } \\
\text { 30mns } \\
\text { Nadi sweda for } 15 \\
\text { mns } \\
\end{array}$ & On 11th day & $\begin{array}{l}\text { Samyak Snigdha and } \\
\text { svinna Lakshanas } \\
\text { observed }\end{array}$ \\
\hline 4 & Vamana Karma & $\begin{array}{c}\text { Vamana Dravya- } \\
\text { Madha phala chooran } \\
\text { Vamanopaga Dravya- } \\
\text { Yasthi Madhu Phanta } \\
\text { Dugdha (milk) } \\
\text { Saindava Lavana } \\
\text { Madhu (honey) }\end{array}$ & $\begin{array}{l}6 \text { gms } \\
2 \text { liters } \\
2 \text { liters } \\
\text { 2gms } \\
\text { Q. S }\end{array}$ & $\begin{array}{l}\text { On } 12^{\text {th }} \text { day } \\
\text { (On the day of } \\
\text { Vamana) }\end{array}$ & $\begin{array}{c}\text { Vamana samyak yoga } \\
\text { Lakshanas observed } \\
\text { Vegas- } 8 \\
\text { Upavegas-6 } \\
\text { Antiki criteria- } \\
\text { pittantam } \\
\text { No complications } \\
\text { Observed }\end{array}$ \\
\hline 5 & $\begin{array}{l}\text { Samsarjana } \\
\text { Krama }\end{array}$ & $\begin{array}{c}\text { Food (peya, vilepi etc) } \\
\text { \& Behavioral regimen } \\
\text { advised }\end{array}$ & & $\begin{array}{l}\text { For } 7 \text { days } \\
\text { (Starting from } \\
\text { the day of } \\
\text { Vamana) }\end{array}$ & \\
\hline
\end{tabular}

Table no. 2: Bhahiparimarjana chikitsa (Advised Bahirparimarjana chikista for 14 days after Shodana Chikista)

\begin{tabular}{|c|c|c|c|c|}
\hline Sl. No & Type of Treatment & $\begin{array}{c}\text { Name of the } \\
\text { Medicine }\end{array}$ & Dose \& Duration & Results \\
\hline 1 & $\begin{array}{c}\text { Avagaha Sweda } \\
\text { (Mridu sweda) }\end{array}$ & $\begin{array}{c}\text { Sukoshna Jala } \\
\text { Lavana }\end{array}$ & $\begin{array}{c}5 \text { litres } \\
15 \text { gms } 15 \mathrm{mns} \text { every day for 14 days }\end{array}$ & $\begin{array}{c}\text { Scales detached } \\
\text { Smell reduced }\end{array}$ \\
\hline 2 & Padhabyanga & Pinda Taila & $\begin{array}{c}20 \mathrm{ml} 15 \mathrm{mns} \\
\text { Every day for } 14 \text { days }\end{array}$ & $\begin{array}{c}\text { Fissures healed } \\
\text { Pain reduced } \\
\text { Skin become soft and } \\
\text { normal color attained. }\end{array}$ \\
\hline
\end{tabular}


Table no 3: Shamana Chikitsa

(Advised Samana Aushadas for one month after completion of Shodana and Padhabyanga)

\begin{tabular}{|c|c|c|c|}
\hline Sl. No & Name of the Medicine & Dose \& Anupana & Duration \\
\hline 1 & Kadhiradi vati & 1BD with water & 30 days \\
\hline 2 & Arogyavardini vati & 1BD with water & 30 days \\
\hline 3 & Aragvadarashita & $15 \mathrm{ml}$ BD with equal water & 30 days \\
\hline
\end{tabular}

Table no 4: Gradation of Subjective parameters

\begin{tabular}{|c|c|c|c|}
\hline $\begin{array}{l}\text { Sl. } \\
\text { No. }\end{array}$ & $\begin{array}{l}\text { Signs and } \\
\text { Symptoms }\end{array}$ & Gradation & \\
\hline \multirow[t]{4}{*}{1} & Pain & No Pain & 0 \\
\hline & & $\begin{array}{l}\text { Mild pain- } \\
\text { tolerable in nature } \\
\text { felt occasionally }\end{array}$ & 1 \\
\hline & & $\begin{array}{l}\text { Moderate Pain- } \\
\text { experience frequently, requires some measures to relieve the pain }\end{array}$ & 2 \\
\hline & & $\begin{array}{l}\text { Severe Pain- } \\
\text { Constant in nature, } \\
\text { disturbs sleep, } \\
\text { requires analgesics }\end{array}$ & 3 \\
\hline \multirow[t]{4}{*}{2} & Itching & No Itching & 0 \\
\hline & & $\begin{array}{l}\text { Mild Itching- } \\
\text { 2-3 times in a day } \\
\text { tolerable in nature }\end{array}$ & 1 \\
\hline & & $\begin{array}{l}\text { Moderate Itching- } \\
\text { frequent episodes of itching, sometimes disturbs the sleep and day time } \\
\text { activities }\end{array}$ & 2 \\
\hline & & $\begin{array}{l}\text { Severe Itching- } \\
\text { Constant itching } \\
\text { frequent sleep disturbances }\end{array}$ & 3 \\
\hline \multirow[t]{4}{*}{3} & Secretions & No Secretions & 0 \\
\hline & & Mild- Secretions on activity & 1 \\
\hline & & $\begin{array}{l}\text { Moderate- } \\
\text { Occasional secretions without activity }\end{array}$ & 2 \\
\hline & & $\begin{array}{l}\text { Severe- } \\
\text { Continuous secretions on rest }\end{array}$ & 3 \\
\hline \multirow[t]{4}{*}{4} & Discoloration & No discoloration & 0 \\
\hline & & $\begin{array}{l}\text { Mild- } \\
\text { Slight discoloration present on palms and soles }\end{array}$ & 1 \\
\hline & & $\begin{array}{l}\text { Moderate- } \\
\text { Discoloration present with slight skin cracks }\end{array}$ & 2 \\
\hline & & $\begin{array}{l}\text { Severe- } \\
\text { Dark dirty discoloration with large cracks }\end{array}$ & 3 \\
\hline \multirow[t]{4}{*}{5} & Roughness & Insignificant & 0 \\
\hline & & $\begin{array}{l}\text { Mild- } \\
\text { Roughness on touch }\end{array}$ & 1 \\
\hline & & $\begin{array}{l}\text { Moderate- } \\
\text { Roughness with itching and cracks }\end{array}$ & 2 \\
\hline & & $\begin{array}{l}\text { Severe- } \\
\text { Roughness with cracks and fissures }\end{array}$ & 3 \\
\hline
\end{tabular}


Padma Priya N et.al., Role of Vamana and Padhabhaynaga in the management of Vipakadika w.s.r. Plantopalmar Psoriasis

Table no 5: Assessment of symptoms of vipadika before and after treatment

\begin{tabular}{|c|c|c|c|}
\hline Sl.no & $\begin{array}{c}\text { Signs and symptoms } \\
\text { (Subjective parameters) }\end{array}$ & Before treatment & After treatment \\
\hline 1 & Pain & 3 & 1 \\
\hline 2 & Itching & 3 & 1 \\
\hline 3 & Secretions & 3 & 0 \\
\hline 4 & Discoloration & 3 & 1 \\
\hline 5 & Roughness & 3 & \\
\hline
\end{tabular}

PICTURES BEFORE AND AFTER TREATMENT

Picture - 1: Left leg before treatment

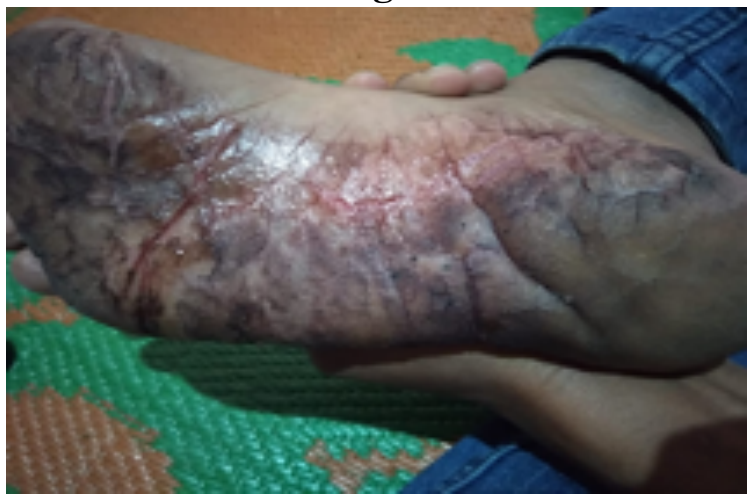

Picture - 3 Right leg before treatment

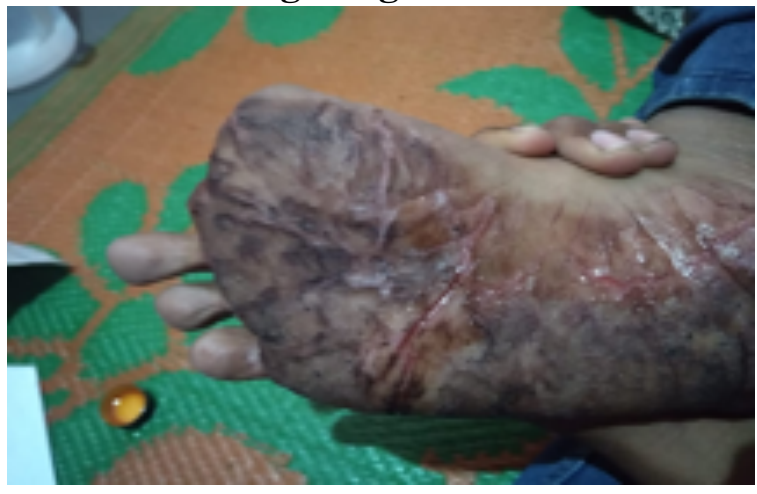

\section{Discussion}

Vipadika is one of the forms of Kshudra Kushta. According to clinical manifestations, it is similar to Planto-palmar psoriasis which is found to be $3-4 \%$ of all psoriasis cases. In the present case study, the treatment given to the patient was in accordance with treatment principles mentioned by Acharya Charaka for Kushta Roga. The principle explains the administration of suitable shodana according to dosha predominance. As Vipadika is a vata kapha predominance Kushta roga, deepana and Pachana were initially administered followed by sneha pana with Maha Tiktaka Gritha for 7 days. This gritha is made up of tikta rasa Pradana and Sheeta veerya dravyas and is mainly beneficial in pitta and vata predominant Kushta rogas mentioned by Acharya Charaka (9) and Vagbhata- (10) After Sneha pana, Abhyanga and Nadi sweda was performed for one day, then conducted Vamana as Shodana therapy. It helped to remove Utklishta kapha dosha along with Alpa piita (11) from the body. In this case study, patient
Picture - 2: Left leg after treatment

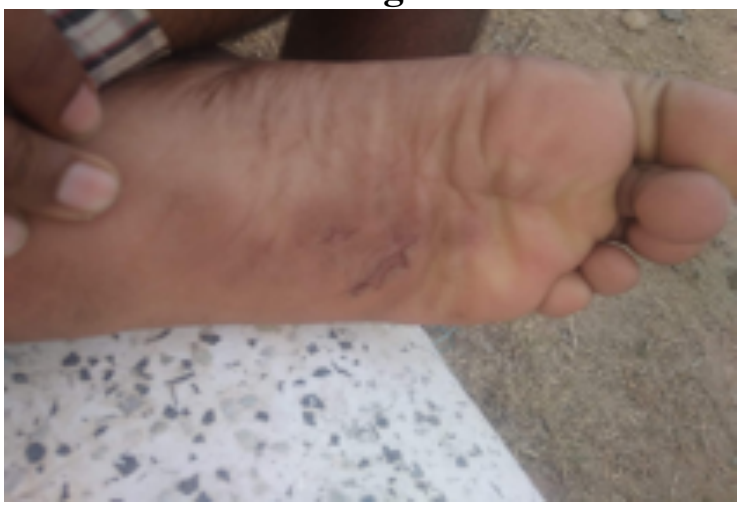

Picture - 4 Right Leg after treatment

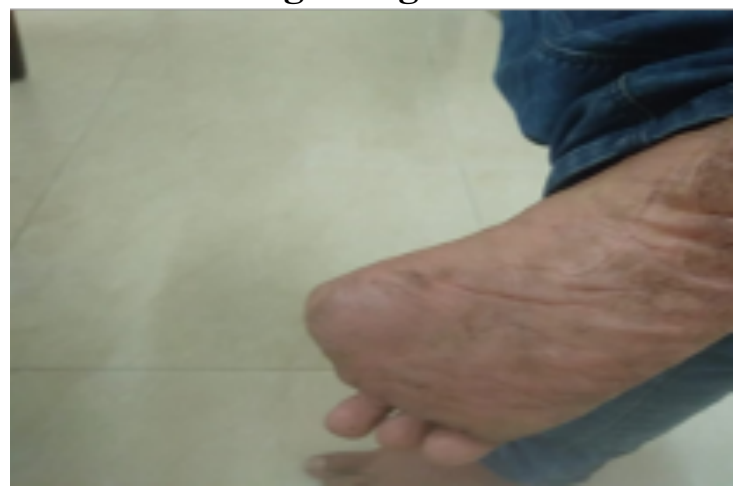

got significant relief from symptoms of Vipadika with Shodana Chikista.

As per Ashtanga Hridaya, mridu Sweda can be given in kushta (12). Accordingly, Mridu Lavana jala Avagaha sweda was administered to pacify Stananugatha vata dosha. Avagaha sweda helps to dissolve kapha which in dense stage stuck to channels firmly, further it liquifies kapha allowing it to move freely, (13) it also makes channels soft due to which vata flows in normal direction. Svedana by its qualities ushna, teekshna gunas increases metabolic rate, dilates the capillaries thereby increases circulation. Thus, increased circulation enhances the elimination of waste products from the body in the form of sweat. As such, sweda karma does cleansing effect in the body. (14) Lavana by its properties like Sukshma, vyavayi, vikasi etc. easily enters into the body (15) and it helps in exfoliating dead skin cells, cleansing skin pores and protecting the natural skin layers to produce healthy skin. It helps in getting rid of toxic minerals and refined salt deposits by stimulating blood circulation. By its 
anti-bacterial action, it prevents secondary infections also. (16)

After cleaning palms and soles with sweda karma, Padhabyanga with pinda taila was performed where oil enters into inner layers of skin and helps in quick healing of cracks giving maximum benefits of Padhabyanga which are mentioned by Acharya Charaka viz. quick relief of roughness, dry ness, fatigue and numbness. It makes legs stable, soft and prevents cracks. (17) Further, Padhabyanga prevents aggravation of vata, kapha doshas and provides good nourishment to the tissues of pada. (18) Thus, helpful in treating Vipadika.

\section{Conclusion}

As Kushta is tridoshaja vyadhi, the line of management followed helped to maintain equilibrium of all the doshas. It gave excellent symptomatic relief to the patient in a short period of time. From the above case study, it can be said that Planto-palmar psoriasis can be successfully managed through Ayurvedic line of management.

\section{References}

1. Philip Abraham, Dastur.FD, Joshi.VR, Lele.RD, Mehta.PJ, Sukumar Mukherjee, Shanker.PS. API TEXT BOOK OF MEDICINE, Gurumukhi S Sainanai, 6th Edition, Reprint 2001, Mumbai; Association of Physicians of India; Section 21, Topic 9,1198p

2. Arend, Armitage, Clemmons, Drazen, Griggs, LaRusso.Cecil Medicine, Goldman, Ausiello,23 ${ }^{\text {rd }}$ Edition, 2008, New Delhi; Elsevier, a division of Reed Elsevier India Private Limited; Volume II, Chapter 464,2941p

3. Ram Karan Sharma, Bhagwan Dash. Charaka Samhita of Acharya Agnivesha. Reprint 2017, Varanasi; Chowkamba Sanskrit Series office;2017, Vol.III, Chikista Sthana, Chapter VII, 325p

4. Srikantha Murthy.K.R. Ashtanga Hridayam of Acharya Vagbhata. Reprint 2018, Varanasi; Chowkamba Krishnadas Academy; 2018, Vol.II, Nidana Sthana, Chapter XIV, 139p

5. Ram Karan Sharma, Bhagwan Dash. Charaka Samhita of Acharya Agnivesha. Reprint 2017, Varanasi; Chowkamba Sanskrit Series office;2017, Vol.III, Chikista Sthana, Chapter VII, 329p

6. Ram Karan Sharma, Bhagwan Dash. Charaka Samhita of Acharya Agnivesha. Reprint 2017,
Varanasi; Chowkamba Sanskrit Series office;2017, Vol.I, Sutra Sthana, Chapter XIV, 278p

7. Srikantha Murthy.K.R. Ashtanga Hridayam of Acharya Vagbhata. Reprint 2018, Varanasi; Chowkamba Krishnadas Academy; 2018, Vol.I, Sutra Sthana, Chapter II, $24 p$

8. N is hteshwar.k, Vidhyanath. R. Sahasrayogam.Reprint 2017, Varanasi; Chowkamba Sanskrit Series Office;2017, Taila Prakarana,120p

9. Ram Karan Sharma, Bhagwan Dash. Charaka Samhita of Acharya Agnivesha. Reprint 2017, Varanasi; Chowkamba Sanskrit Series office;2017, Vol.III, Chikista Sthana, Chapter VII, 355p

10. Srikantha Murthy.K.R. Ashtanga Hridayam of Acharya Vagbhata. Reprint 2018, Varanasi; Chowkamba Krishnadas Academy; 2018, Vol.II, Chikista Sthana, Chapter XIX, 473p

11. Srikantha Murthy.K.R. Ashtanga Hridayam of Acharya Vagbhata. Reprint 2018, Varanasi; Chowkamba Krishnadas Academy; 2018, Vol.I, Sutra Sthana, Chapter XVIII, 225p

12. Srikantha Murthy.K.R. Ashtanga Hridayam of Acharya Vagbhata. Reprint 2018, Varanasi; Chowkamba Krishnadas Academy; 2018, Vol.I, Sutra Sthana, Chapter XVII, 223p

13. Ram Karan Sharma, Bhagwan Dash. Charaka Samhita of Acharya Agnivesha. Reprint 2017, Varanasi; Chowkamba Sanskrit Series office;2017, Vol.IV, Chikista Sthana, Chapter XVII, 136p

14. Vasanth C. Patil. Principles and Practice of Panchakarma. Reprint 2017, New Delhi; Chowkamba Publications;2017, Chapter IX,247p

15. Ram Karan Sharma, Bhagwan Dash. Charaka Samhita of Acharya Agnivesha. Reprint 2017, Varanasi; Chowkamba Sanskrit Series office;2017, Vol.I, Sutra Sthana, Chapter XIII, 267p

16. Neelesh Khandelwal, Shradha Dhundi, Pramod Yadav, Prajapati P.K. Lavana(salt): An Ayurvedic Outlook On Saindava (Rock Salt), April-June 2012, Volume 5 Number 2, Indian Journal of Ancient Medicine and Yoga.

17. Ram Karan Sharma, Bhagwan Dash. Charaka Samhita of Acharya Agnivesha. Reprint 2017, Varanasi; Chowkamba Sanskrit Series office;2017, Vol.I, Sutra Sthana, Chapter V, 125p

18. Singhal.G.D. Susruta Samhita of Acharya Susruta. Reprint 2015, Delhi; Chowkamba Sanskrit Pratishthan; 2015. Vol.II, Chapter XXIV, 379p. 